Article

\title{
One-Stage Calcium Carbonate Oil-Based Filter Cake Removal Using a New Biodegradable Acid System
}

\author{
Salaheldin Elkatatny \\ College of Petroleum Engineering and Geosciences, King Fahd University of Petroleum \& Minerals, Dhahran \\ 31261, Saudi Arabia; elkatatny@kfupm.edu.sa
}

Received: 29 August 2019; Accepted: 12 October 2019; Published: 16 October 2019

\begin{abstract}
Removal of the oil-based filter cake is a complex task especially in horizontal and multilateral wells. The presence of oil makes the removal process more challenging because the oil coats the weighting materials and prevents acid-filter cake interaction. Therefore, different additives are required to change the wettability of the filter cake to enhance the removal efficiency. This paper introduces a new biodegradable acid system (NBAS) that can efficiently remove oil-based filter cake in horizontal and multilateral wells where calcium carbonate is used as a weighting agent. The new biodegradable acid system (NBAS) consists of 50 vol.\% biodegradable acid and 5 vol.\% mutual solvent, and the remaining percent is deionized water. High-pressure high-temperature (HPHT) filtration experiments were performed to evaluate the filter cake removal efficiency and the retained permeability. The filtration and removal experiments were conducted using real core samples (Indiana limestone and Berea sandstone) at a temperature of $212^{\circ} \mathrm{F}$ and 300 psi differential pressure. Afterward, the NBAS was evaluated by measuring physical properties and conducting corrosion, compatibility, and thermal stability studies. The obtained results showed that the NBAS was compatible and thermally stable for more than $48 \mathrm{~h}$ at $212^{\circ} \mathrm{F}$ and $300 \mathrm{psi}$. The NBAS has a density of $1.05 \mathrm{~g} / \mathrm{cm}^{3}$, viscosity of $1.47 \mathrm{cP}$, and surface tension of $32 \mathrm{dynes} / \mathrm{cm}$ at room temperature. The corrosion rate of the developed system was $0.03 \mathrm{lb} / \mathrm{ft}^{2}$, which is acceptable according to oil and gas industry best practices. Removal experiments showed that the filter cake was completely removed from the core samples. For Berea sandstone, $100 \%$ of the permeability was regained, while the retained permeability for Indiana limestone was $122.5 \%$, confirming the complete removal of external and internal filter cake as well as core samples stimulation. The new acid system can be considered as an efficient solution for oil-based filter cake removal that is biodegradable and cost-effective, where the reservoir permeability can be regained in one-stage only.
\end{abstract}

Keywords: oil-based filter cake; one-stage; calcium carbonate; biodegradable; horizontal well

\section{Introduction}

Overbalanced drilling is the most common technique for drilling oil and gas wells, where the hydrostatic pressure of the drilling fluid is kept higher than the formation pressure to prevent any production while drilling. Consequently, the drilling fluid tends to invade the formation, interacting with the solid and fluid components, causing permanent or removable formation damage. To mitigate the formation damage caused by the fluid filtrate invasion, drilling fluid formulation should be optimized by selecting the appropriate loss circulation additives that help form an ideal filter cake, thin and impermeable, on the wall of the drilled well [1,2]. Figure 1 shows a schematic of the filter cake through the wellbore. This filter cake saves the integrity of the wellbore during the drilling operation and reduces the fluid filtrate invasion [3-6]. To avoid any production restraint, the filter cake must be removed after completing drilling operations and before commencing production [7]. 


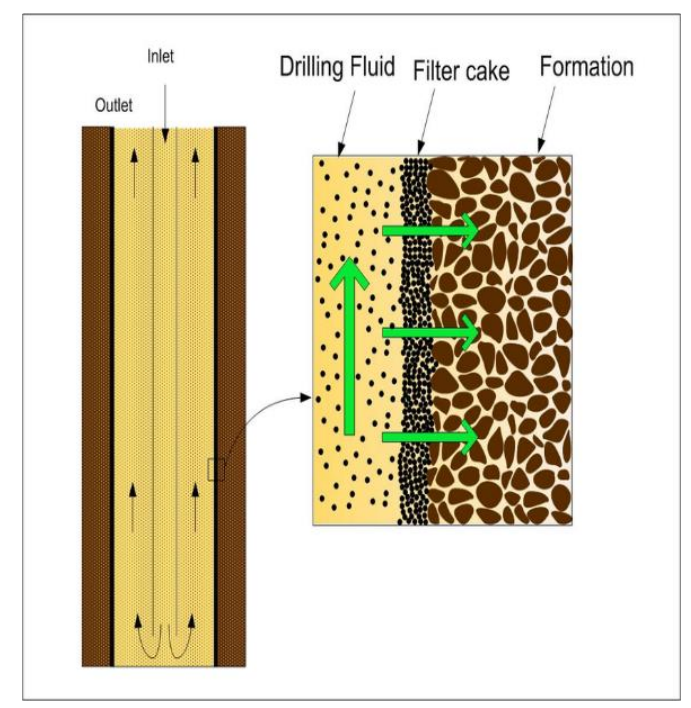

Figure 1. Schematic of the formed filter cake at the top of the rock surface.

Davidson et al. [8] and Jiao et al. [9] stated that the well productivity can be significantly reduced because of plugging the completion screen by drill-in fluid (DIF) solids, which build a rigid barrier filter cake at the face of the formation. Formation damage is a common issue in the drilling operation because of poor design of the drill-in fluid, variation in the reservoir quality (porosity and permeability), lithology, pore-size distribution, and depletion of formation pressure [8].

Formation damage caused by the drill-in fluid is more pronounced in horizontal wells than in deviated or vertical wells because of the longer exposure to the drilling fluid $[10,11]$. Removal of the filter cake and mitigation of the formation damage in horizontal carbonate reservoirs using $\mathrm{HCl}$ acid is a challenging and expensive task because of the large volume of acid consumed due to fast reaction, the heterogeneity of the horizontal section, and the difficulty of acid placement at the appropriate locations [12-14].

Oil-based mud is the most common drilling fluid used to drill the reservoir section [15]. However, removal of a filter cake formed by oil-based drilling fluid is a challenging task as the oily film coating the weighting materials prevents acid-filter cake interaction. Consequently, some additives are required to alter the wettability of the filter cake to have a direct interaction between the acid and bridging agents to enhance the removal efficiency [16].

Many research studies were conducted to remove oil-based filter cake. Al-Anzi et al. [17] stated that the invert-emulsion filter cake can be uniformly removed using a delayed filter cake breaker. The organic acid precursor (OAP) is the main component in the delayed filter cake breaker in addition to water wetting additives [18]. Zubail et al. [19] used an organic acid precursor (OAP) and a water wetting additive to remove the invert-emulsion filter cake after drilling horizontal wells in Safaniya Offshore Field in Saudi Arabia. They concluded that the filter cake breaker which contains OAP and water wetting agents had a uniform distribution in the horizontal section and the breaker was able to remove the filter cake completely. Zubail et al. [19] stated that one of the main disadvantages of the OAP system is that it releases acid that can cause corrosion to the screen and the tubular system.

A microemulsion is a very stable homogenous fluid that was formulated by adding alcohol to surfactant-stabilized oil in water emulsions [20]. It can be used to dissolve the filter cake of synthetic and oil-based filter cakes in open-hole completions [21]. Microemulsion consists of several phases separated by a monolayer of surfactant. The average droplet size of the microemulsion is 10 to $100 \mathrm{~nm}$, which is much smaller than conventional emulsions [22-25]. There are many factors affecting the behavior of the microemulsion phase, such as oil type, surfactant, co-surfactant, salinity, and temperature. Because wells are not identical, a preliminary study should be conducted in a laboratory considering the specific conditions of each well [26]. 
Invert emulsion drill-in fluid is commonly used to drill Saudi Arabia sandstone reservoirs to eliminate the formation damage caused by clay swelling. Al-Otaibi et al. [27] developed a single-stage removal fluid for oil-based filter cake in horizontal wells using single-phase microemulsion. They concluded that microemulsion was able to remove the invert-emulsion drill-in fluid filter cake with a high efficiency of $97 \%$ in 24 h soaking. They stated that the single-phase microemulsion was compatible with the invert-emulsion drilling fluid. However, the main advantages of microemulsion fluids are a reduction in the interfacial tension to near zero, high diffusion coefficient, and high oil solubilization [26].

Kumar et al. [28] used a single-phase microemulsion fluid where surfactants and co-surfactants were used to co-solubilize oil and water. They concluded that microemulsion fluids were able to effectively remove synthetic and oil-based filter cake and the near-wellbore damage. For successful operations, the microstructure of microemulsion should be characterized to customize the microemulsions for a certain application $[29,30]$.

Zhou et al. [31] developed a new fluid formulation to remove oil-based filter cake. Their formulation consists of an oxidant (persulfate salt) and a nonionic surfactant. They stated that the main parameters that should be optimized are the type and the number of persulfates. They concluded that the new formulation is cost-effective and can be done in one stage only, with a removal efficiency up to $98 \mathrm{wt} . \%$, with a minimal effect on the formation permeability.

This study introduces a new biodegradable acid system to remove oil-based filter cake which contains calcium carbonate as a weighting agent. The new formulation consists of $50 \mathrm{vol} . \%$ biodegradable acid, 5 vol. \% mutual solvents, and 45 vol.\% deionized water. A complete evaluation of the new fluid formulation was performed by assessing the removal efficiency, measuring the retained permeability after the removal process, and conducting compatibility, stability, and corrosion tests.

\section{Materials}

Invert-emulsion drilling fluid was prepared which contains $210 \mathrm{~cm}^{3}$ of diesel as the continuous phase and $59.5 \mathrm{~cm}^{3}$ of water as the dispersed phase. Calcium carbonate $(30 \mathrm{~g})$ was added as a weighting material, Invermul ( $6 \mathrm{~g})$ as a primary emulsifier, and EZ-Mul as a secondary emulsifier ( $3 \mathrm{~g})$. Lime $(8 \mathrm{~g})$ was used for contamination treatment and to enhance emulsion stability. Geltone $(9 \mathrm{~g})$ and duratone $(8 \mathrm{~g})$ were used for viscosity and fluid-loss control, respectively. Table 1 lists the drilling fluid components used in this study. The drilling fluid has a plastic viscosity of $37.5 \mathrm{cP}$ and a yield point of $30 \mathrm{lb} / 100 \mathrm{ft}^{2}$, while the gel strength was $17 \mathrm{lb} / 100 \mathrm{ft}^{2}$ at $10 \mathrm{sec}, 20 \mathrm{lb} / 100 \mathrm{ft}^{2}$ at $10 \mathrm{~min}$, and $23 \mathrm{lb} / 100 \mathrm{ft}^{2}$ at $30 \mathrm{~min}$. The minor increase in the gel strength value from $10 \mathrm{~min}$ to $30 \mathrm{~min}$ indicates the flat rheology profile of the drilling fluid.

Table 1. The drilling fluid formula used in this study.

\begin{tabular}{cc}
\hline Additive & Quantity \\
\hline Diesel & $210 \mathrm{~cm}^{3}$ \\
\hline INVERMUL NT & $6 \mathrm{~g}$ \\
\hline EZ-MUL NT & $3 \mathrm{~g}$ \\
\hline LIME & $8 \mathrm{~g}$ \\
\hline Water & $59.5 \mathrm{~cm}^{3}$ \\
\hline $\mathrm{CaCl}_{2}$ & $44 \mathrm{~g}^{2}$ \\
\hline GELTONE II $^{\mathrm{g}}$ \\
\hline DURATONE HT & $8 \mathrm{~g}$ \\
\hline $\mathrm{CaCO}_{3}$ & $30 \mathrm{~g}$ \\
\hline
\end{tabular}


NBAS (new biodegradable acid system) consists of 50 vol. \% biodegradable acid, 5 vol. $\%$ mutual solvent, and $45 \mathrm{vol} . \%$ deionized water. The biodegradable acid, obtained from a service company, is a green acid solution synthesized by a catalytic-reagent combination added to $\mathrm{HCl}$. The biodegradable acid was used to dissolve the formed filter cake. It has a density of $1.05 \mathrm{gm} / \mathrm{cm}^{3}$, a viscosity of $1.47 \mathrm{cP}$, surface tension of $32 \mathrm{mN} / \mathrm{m}$, and a $\mathrm{pH}$ of -1.29 . These properties were measured at ambient temperature. The mutual solvent (Ethylene Glycol Mono Butyl Ether, $\mathrm{C}_{6} \mathrm{H}_{14} \mathrm{O}_{2}$ ), obtained from a chemical service company, was used to alter the wettability of the filter cake to enhance the acid-filter cake reaction.

Two different core samples were used as filtration medium to simulate the reservoir condition; Indiana limestone core (2.5" in diameter) with an average diesel permeability of $166.6 \mathrm{mD}$ and average porosity of $14.77 \%$, and Berea sandstone core (2.5" in diameter) with an average diesel permeability of $133.6 \mathrm{mD}$ and an average porosity of $17.9 \%$. The core was dried for three $\mathrm{h}$ at $200{ }^{\circ} \mathrm{F}$ in the oven, then it was saturated with the diesel for $24 \mathrm{~h}$ under vacuum to be sure that it is saturated $100 \%$ with diesel. Figure 2 shows the core samples photos, and Table 2 list the properties of the used core samples.

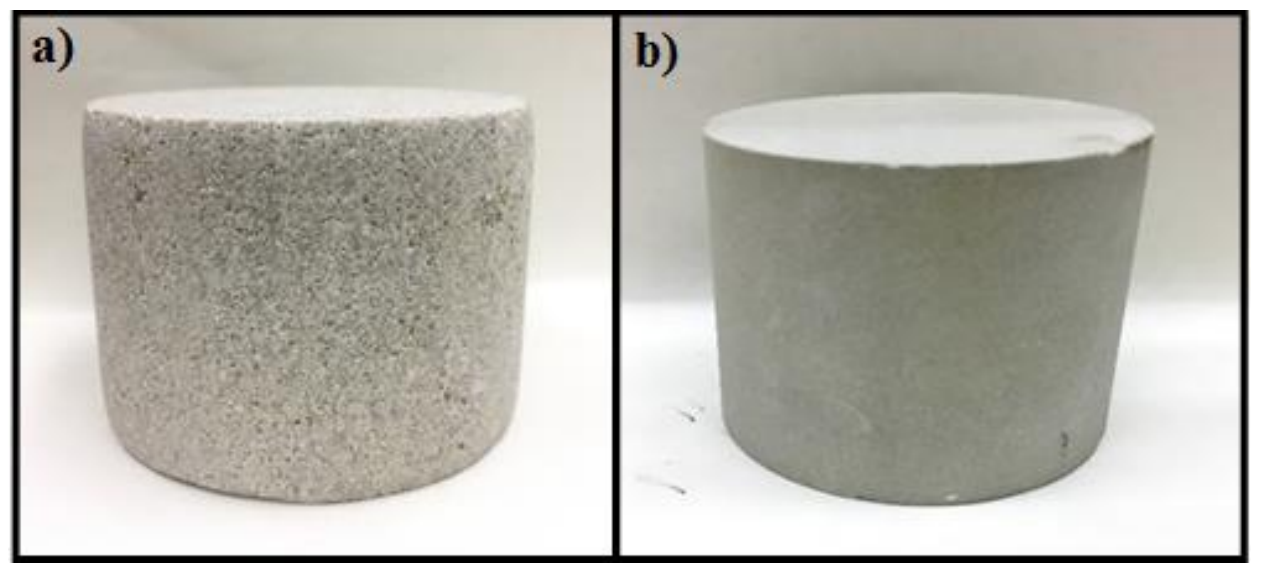

Figure 2. The used core samples: (a) Limestone and (b) Sandstone.

Table 2. Core sample properties.

\begin{tabular}{ccc}
\hline Property & Limestone & Sandstone \\
\hline Diameter, in & 2.5 & 2.5 \\
\hline Permeability with diesel, $\mathrm{mD}$ & 166.6 & 133.6 \\
\hline Porosity, $\%$ & 14.78 & 17.90 \\
\hline
\end{tabular}

\section{Experimental Procedure}

The following procedure was applied to evaluate the performance of the NBAS in removing the oil-based calcium carbonate filter cake:

- The density, viscosity, and surface tension of the NBAS was measured at ambient temperature.

- Compatibility and thermal stability of the new acid mixture were performed at room temperature and $212^{\circ} \mathrm{F}$ for $24 \mathrm{~h}$.

- A corrosion test was conducted at $212^{\circ} \mathrm{F}$ and 300 psi using steel coupons for $6 \mathrm{~h}$, and the results were compared with an equivalent concentration of $\mathrm{HCl}$.

- Invert-emulsion drilling fluid was prepared and mixed under ambient conditions using a three-speed mud mixer.

- Drilling fluid rheology was measured at $120^{\circ} \mathrm{F}$ and atmospheric pressure.

- High-pressure high-temperature (HPHT) filtration tests were performed using 2.5" core samples for $30 \mathrm{~min}$ at $212^{\circ} \mathrm{F}$ and 300 psi differential pressure. 
- HPHT removal tests were performed using $200 \mathrm{~cm}^{3}$ of the new acid system to evaluate the filter cake removal efficiency after $24 \mathrm{~h}$ under static conditions.

\section{Results and Discussions}

\subsection{Evaluation of NBAS}

The properties of the NBAS were measured at room temperature. These properties are density, viscosity, and surface tension. NBAS has a density of $1.05 \mathrm{~g} / \mathrm{cm}^{3}$, viscosity of $1.47 \mathrm{cP}$, and surface tension of 32 dynes $/ \mathrm{cm}$.

Compatibility and stability studies were performed at room temperature to evaluate the stability of the new acid system. A see-through cell was used to evaluate the thermal stability of the acid system at high temperature $\left(212^{\circ} \mathrm{F}\right)$. The acid system was compatible under room temperature and $212{ }^{\circ} \mathrm{F}$ for more than $24 \mathrm{~h}$ without any change in the fluid system. No evidence of cloud formation was observed.

The corrosion rate was performed using a $100 \mathrm{~cm}^{3}$ solution, which contains $25 \mathrm{vol} . \%$ and $50 \mathrm{vol} . \%$ of NBAS at $212^{\circ} \mathrm{F}$ and 300 psi applied presser using aging cell. Figure 3 shows that the corrosion rate was $0.032 \mathrm{lb} / \mathrm{ft}^{2}$ when using $50 \%$ by volume of NBAS. Whereas it was $0.025 \mathrm{lb} / \mathrm{ft}^{2}$ by decreasing the concentration of NBAS to $25 \mathrm{vol} . \%$ at $212{ }^{\circ} \mathrm{F}$. Figure 4 shows the steel coupon before and after the corrosion test when using $50 \%$ by volume of NBAS.

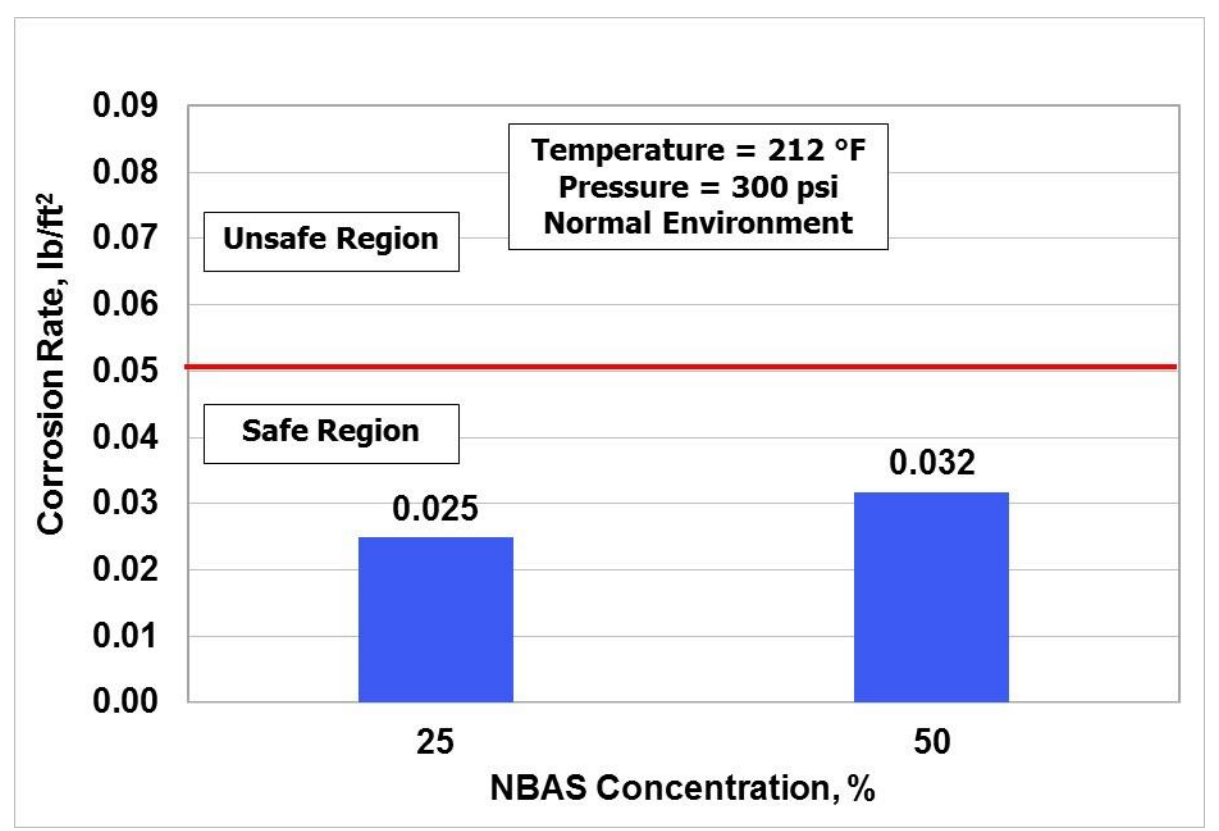

Figure 3. The corrosion rate of different concentrations of NBAS (new biodegradable acid system).

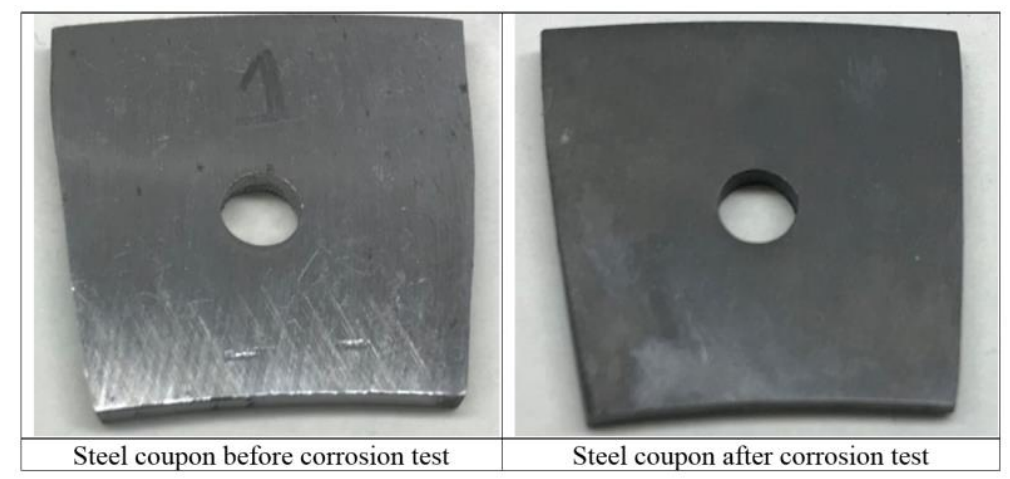

Figure 4. Steel coupon before and after the corrosion test using 50 vol. $\%$ of NBAS at $212^{\circ} \mathrm{F}$. 


\subsection{Comparison with 10 vol.\% $\mathrm{HCl}$}

The titration test was performed for the solution of NBAS and it showed that the concentration of the converted $\mathrm{HCl}$ is 20 vol.\%. In our experiments, 50 vol.\% of NBAS was used, which means that the active converted $\mathrm{HCl}$ is almost $10 \mathrm{vol} . \%$.

The corrosion rate was conducted at $212^{\circ} \mathrm{F}$ and $300 \mathrm{psi}$ applied pressure using $10 \mathrm{vol} . \%$ conventional $\mathrm{HCl}$, and the results showed that the corrosion rate was very high and bypassed the unsafe region. Figure 5 shows that the corrosion rate using $10 \mathrm{vol} . \% \mathrm{HCl}$ was $0.68 \mathrm{lb} / \mathrm{ft}^{2}$, which is very high compared with the corrosion rate when using 50 vol. $\%$ NBAS at the same condition.

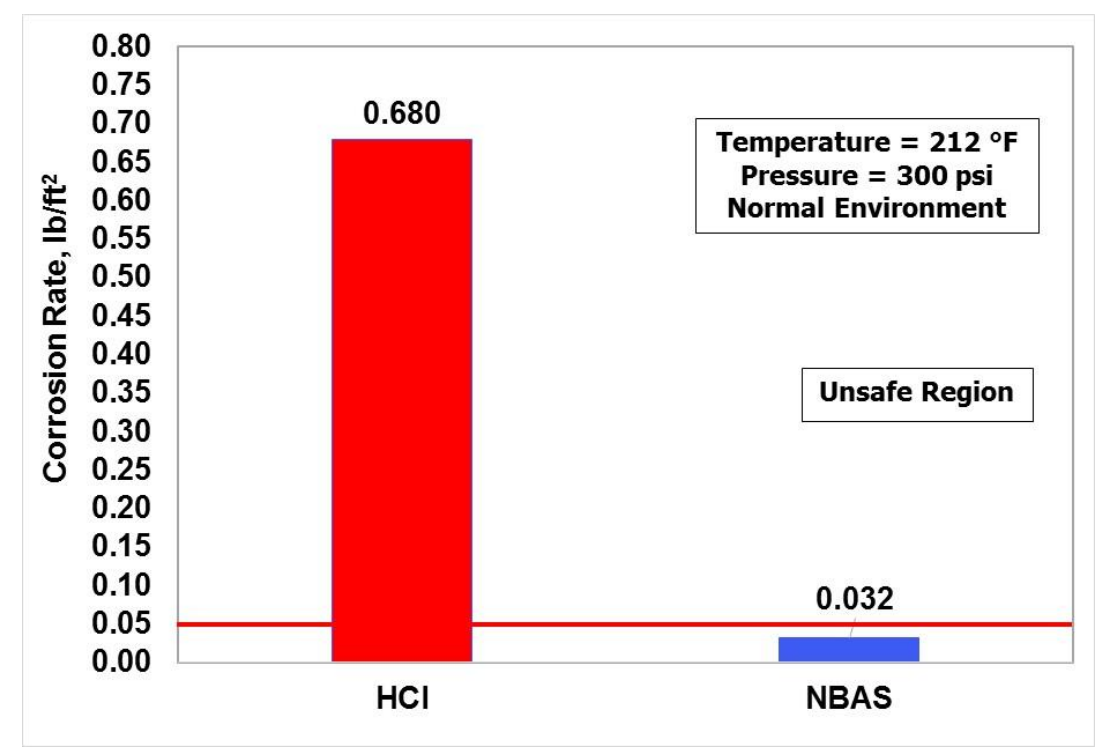

Figure 5. Corrosion rate comparison between $10 \mathrm{vol} \% \mathrm{HCl}$ and $50 \mathrm{vol} \%$ NBAS.

\subsection{HPHT Filtration Tests}

Filtration tests were conducted to form the filter cake for removal tests. The drilling fluid sample was poured into a modified HPHT cell that contained two real core samples (Indiana limestone and Berea sandstone) with 2.5" diameter and around 2" length. Core samples were saturated using diesel. The filtration experiments were performed at a temperature of $212^{\circ} \mathrm{F}$ and a differential pressure of $300 \mathrm{psi}$. The experiment was started, and the filtrate volume was recorded for $30 \mathrm{~min}$. Figure 6 compares the filtrate volume of the invert-emulsion drilling fluid on both Indiana limestone and Berea sandstone during the filtration test. The total fluid filtrate invading the sandstone core sample was $5 \mathrm{~cm}^{3}$, while it was $4 \mathrm{~cm}^{3}$ in case of the limestone core sample. After the filtration tests, a filter cake with a thickness of $1.3 \mathrm{~mm}$ was formed on the sandstone core sample, while the filter cake thickness was $1 \mathrm{~mm}$ in case of the limestone core sample. Figure 7 shows the core samples with the resulted filter cake after the filtration test. 


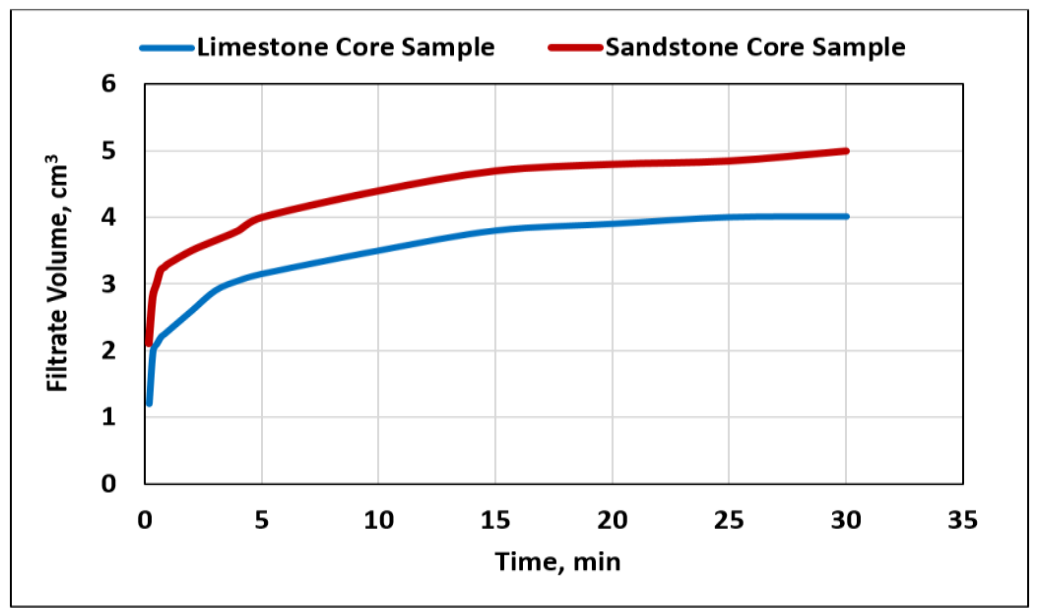

Figure 6. Filtration performance of the invert-emulsion drilling fluid at $212^{\circ} \mathrm{F}$.

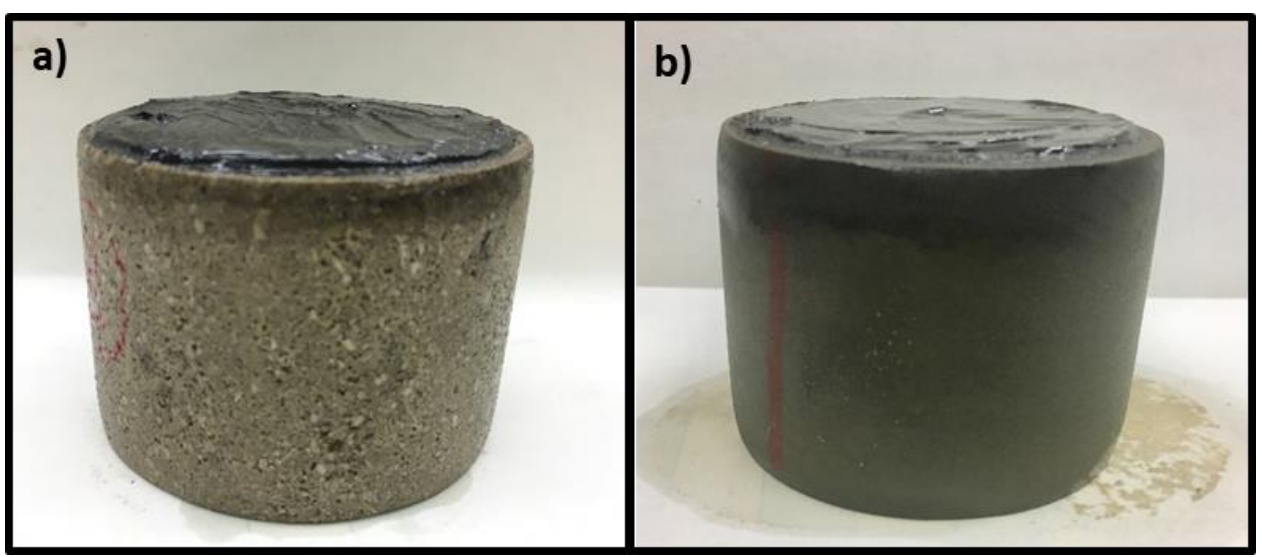

Figure 7. Core samples after filtration tests: (a) Limestone, and (b) Sandstone.

\subsection{Filter Cake Removal and Retained Permeability Calculations}

The HPHT removal tests were performed at $212^{\circ} \mathrm{F}$ to evaluate the removal efficiency of the filter cake using NBAS on limestone and sandstone core samples. The removal tests were conducted by soaking the core sample with the filter cake in $200 \mathrm{~cm}^{3}$ of NBAS for $24 \mathrm{~h}$. The clean-up fluid contains $50 \mathrm{wt} . \%$ NBSA, $5 \mathrm{wt} . \%$ mutual solvent, and the remaining percent is de-ionized water. Figure 8 shows the limestone and sandstone core samples after the removal test. It is clear that the filter cake was completely removed after $24 \mathrm{~h}$ of soaking with NBAS for both limestone and sandstone core samples. These results confirmed the $100 \%$ removal of the external filter cake. To evaluate the removal of the internal filter cake or the damage after the filtration, the return permeability was calculated.

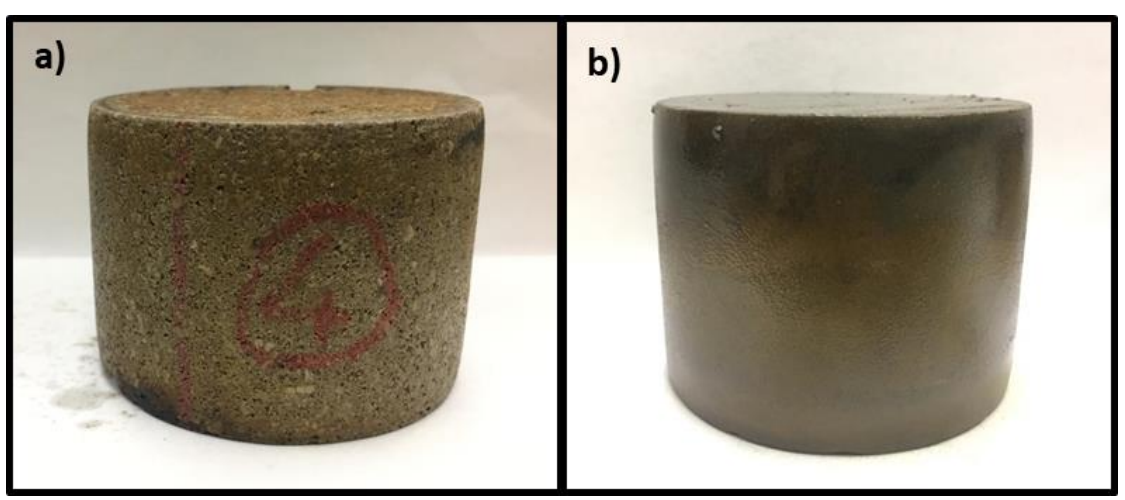

Figure 8. Core samples after soaking with NBAS for $24 \mathrm{~h}$ at $212^{\circ} \mathrm{F}$ : (a) Limestone and (b) Sandstone. 
A modified HPHT filter cell was used to measure the initial and final permeability using diesel at room temperature. The final permeability of the sandstone core was $133.6 \mathrm{mD}$, which is the same value of the initial permeability, indicating the complete removal of the internal damage after the removal process, and the retained permeability was $100 \%$. For the limestone core, the initial permeability was $166.3 \mathrm{mD}$, while the final permeability was $204.14 \mathrm{mD}$, and the retained permeability was $122.5 \%$ (Figure 9). These results confirmed that the new acid formulation was able to stimulate the limestone core sample after removing the external filter cake completely. The filtration and removal tests were conducted three times to confirm the results. Table 3 summarizes the filtration and removal test results.

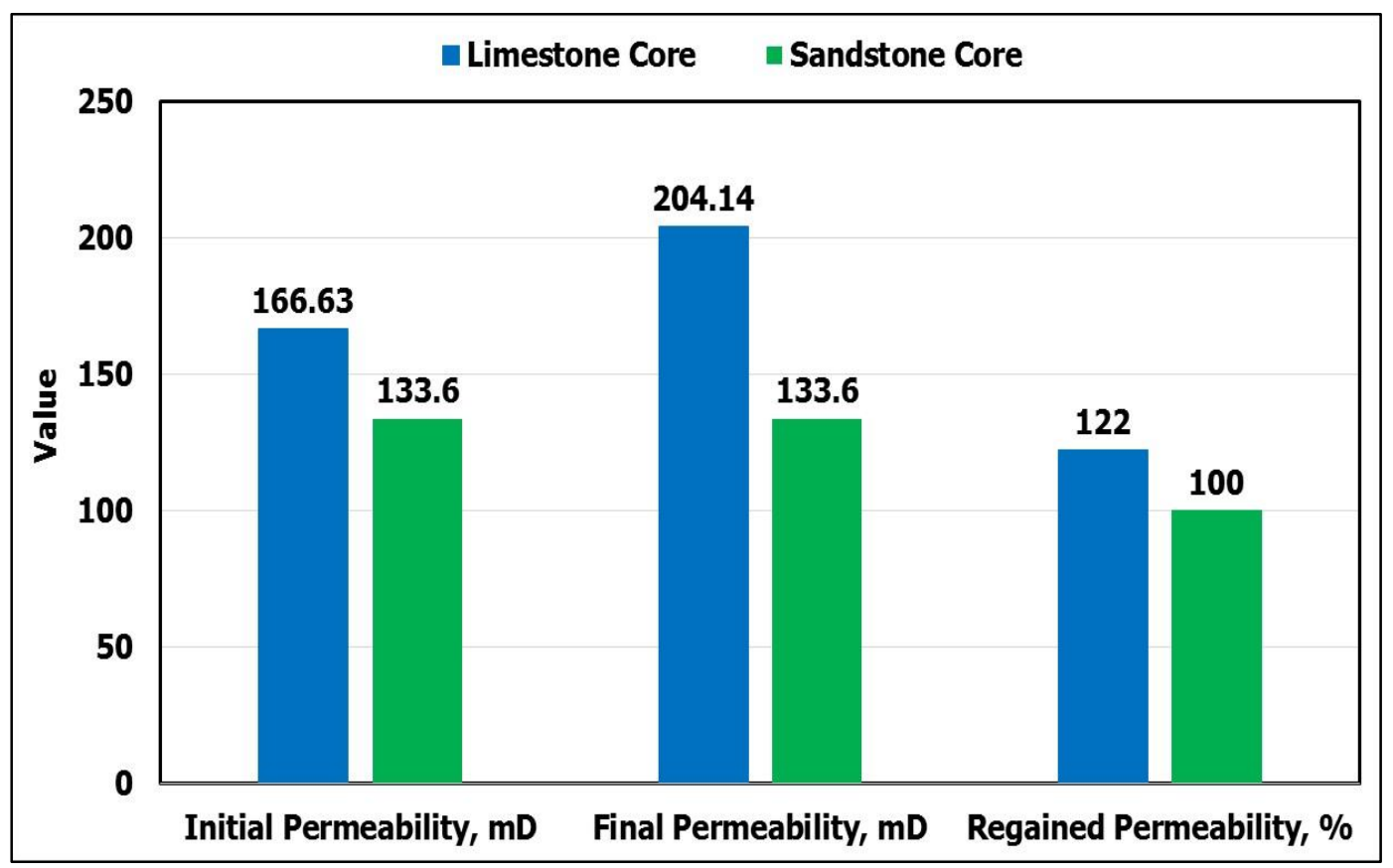

Figure 9. Retained permeability for different cores after using NBAS for $24 \mathrm{~h}$ at $212{ }^{\circ} \mathrm{F}$ for filter cake removal.

Table 3. Summary of filtration and removal tests results.

\begin{tabular}{ccc}
\hline Parameter & Limestone & Sandstone \\
\hline Filter cake weight, $\mathrm{g}$ & 3.5 & 3.9 \\
\hline Filter cake thickness, $\mathrm{mm}$ & 1 & 1.3 \\
\hline Removal efficiency, wt. $\%$ & 125 & 100 \\
\hline Retained permeability, $\%$ & 122 & 100 \\
\hline
\end{tabular}

The mutual solvent ( $5 \mathrm{wt} . \%$ ) was used to remove the oil film surrounding the solid particles, and as a result, there was direct contact between the solid particles and NBAS acid. NBAS (50 wt.\% concentration of the removable fluid) contains $\mathrm{HCl}$ with a concentration of $10 \mathrm{wt} . \%$, which completely removed the calcium carbonate from the filter cake, and the remaining amount of acid interacted and stimulated the core. This explained the increase in retained permeability in the case of limestone.

\section{Conclusions}

A new biodegradable acid system (NBAS) was used to remove the calcium carbonate filter cake formed from invert-emulsion drilling fluids. Based on the results of this study, the following conclusions can be drawn: 
- A new acid formulation was developed to remove calcium carbonate filter cake in invert-emulsion drilling fluids. The new formulation consists of 50 vol. $\%$ biodegradable acid, 5 vol. $\%$ mutual solvent, and 45 vol.\% deionized water.

- The new acid system was found to be very effective in removing calcium carbonate oil-based filter cake in both limestone and sandstone formations, with a removal efficiency of $125 \%$ and $100 \%$, respectively. After the acid treatment, the initial permeability of limestone and sandstone core samples was completely regained with further stimulation on limestone core samples $(122 \%$ retained permeability)

- Compatibility and stability results confirmed that the new acid system is compatible and thermally stable for more than $24 \mathrm{~h}$ under a temperature up to $212^{\circ} \mathrm{F}$ with an acceptable corrosion rate of $0.03 \mathrm{lb} / \mathrm{ft}^{2}$ according to oil industry best practices, which makes this new acid formulation a good candidate for the removal of calcium carbonate filter cake in invert-emulsion drilling fluids.

Funding: This research received no external funding.

Acknowledgments: The authors wish to acknowledge King Fahd University of Petroleum and Minerals (KFUPM) for utilizing the various facilities to carry out this research. Special acknowledge to Enviroklean Product Development, Inc. (EPDI) and Maeen Companied for providing the acid system.

Conflicts of Interest: The author declares no conflict of interest.

\section{References}

1. Li, M.; Wu, Q.; Song, K.; Qing, Y.; Wu, Y. Cellulose Nanoparticles as Modifiers for Rheology and Fluid Loss in Bentonite Water-based Fluids. ACS Appl. Mater. Interfaces 2015, 7, 5006-5016. [CrossRef] [PubMed]

2. He, B.; Li, Z.; Zhao, D.; Liu, H.; Zhong, Y.; Ning, J.; Zhang, Z.; Wang, Y.; Hu, Y. Fabrication of Porous Cu-Doped BiVO4 Nanotubes as Efficient Oxygen-Evolving Photocatalysts. ACS Appl. Nano Mater. 2018, 1, 7039-7051. [CrossRef]

3. Hamzaoui, B.; Al-Moajil, A.M.; Caliskan, S.; Aldarweesh, S.S. Filter Cake Buildup in Horizontal Wells: Characterization and Impact on Removal Operation. In Proceedings of the IADC/SPE Asia Pacific Drilling Technology Conference, Bangkok, Thailand, 27-29 August 2018.

4. Rugang, Y.; Guancheng, J.; Wei, L.; Tianqing, D.; Hongxia, Z. Effect of water-based drilling fluid components on filter cake structure. Powder Technol. 2014, 262, 51-61. [CrossRef]

5. Ba Geri, B.S.; Mahmoud, M.A.; Al-Mutairi, S.H.; Abdulraheem, A. Filter Cake Porosity and Permeability Profile Along the Horizontal Well and Their Impact on Filter Cake Removal. In Proceedings of the International Petroleum Technology Conference, Doha, Qatar, 6-9 December 2015.

6. Ba geri, B.S.; Mahmoud, M.A.; Al-Mutairi, S.H.; Abdulraheem, A. Effect of Sand Content on the Filter Cake Properties and Removal During Drilling Maximum Reservoir Contact Wells in Sandstone Reservoir. J. Energy Resour. Technol. 2016, 138, 32901. [CrossRef]

7. Nasrallah, M.; Vinci, M. New Filter-Cake Breaker Technology Maximizes Production Rates by Removing Near-Wellbore Damage Zone with Delay Mechanism Designed for High Temperature Reservoirs: Offshore Abu Dhabi. In Proceedings of the SPE Asia Pacific Oil \& Gas Conference and Exhibition, Brisbane, Australia, 23-25 October 2018.

8. Davidson, J.M.; Jones, M.; Shuchart, C.E.; Gerard, C. Oil-Based Muds for Reservoir Drilling: Their Performance and Cleanup Charateristics. In Proceedings of the SPE International Symposium on Formation Damage Control, Lafayette, Louisiana, 23-24 February 2000.

9. Jiao, D.; Sharma, M. Formation Damage Due to Static and Dynamic Filtration of Water Based Muds. In Proceedings of the International Symposium on Formation Damage Control, Lafayette, Louisiana, 26-27 February 1992.

10. Thomas, B.; Sharma, M.M. Distribution of Mud Induced Damage Around HorizontalWellbores. In Proceedings of the SPE International Symposium on Formation, Lafayette, LA, USA, 18-19 February 1998.

11. Frick, T.P.; Economides, M.J. Horizontal Well Damage Characterization and Removal. SPE Prod. Facil. 1993, 8, 15-22. [CrossRef] 
12. Parlar, M.; Tibbles, R.J.; Chang, F.F.; Fu, D.; Morris, L.; Davison, M.; Vinod, P.S.; Wierenga, A. Laboratory Development of a Novel, Simultaneous Cake-Cleanup and Gravel-Packing System for Long, Highly-Deviated or Horizontal Open-Hole Completions. In Proceedings of the European Petroleum Conference, The Hague, The Netherlands, 20-22 October 1998.

13. Price-Smith, C.; Bennett, C.; Ali, S.A.; Hodge, R.M.; Burton, R.C.; Parlar, M. Open Hole Horizontal Well Cleanup in Sand Control Completions: State of the Art in Field Practice and Laboratory Development. In Proceedings of the European Petroleum Conference, The Hague, The Netherlands, 20-22 October 1998.

14. Bazin, B.; Longeron, D. Carbonate Acidizing: A Physical Simulation of Well Treatments. In Proceedings of the International Symposium Proceedings, Society of Core Analysts, CD-ROM, 2000. Available online: http://www.ux.uis.no/ \{\}s-skj/ipt/Proceedings/SCA.1987-2004/1-SCA2000-42.pdf (accessed on 10 August 2019).

15. Vickers, S.; Bruce, S.; Hutton, A.; Nunzi, P. Protect and Inject: Optimized Well Fluids Successfully Drill Depleted Reservoirs to Store Gas. In Proceedings of the SPE European Formation Damage Conference, Noordwijk, The Netherlands, 7-10 June 2011.

16. Davidson, E.; McMillan, D.N.; Martin, F.; Morton, K.; Lenz, R. Successful Deployment of a New Stimulation Chemical, Post Horizontal Open-Hole Gravel Pack in Wells Drilled with both Water-Based and Oil-Based Drill-In Fluid. In Proceedings of the SPE/IADC Indian Drilling Technology Conference and Exhibition, Mumbai, India, 16-18 October 2006.

17. Al-Anzi, N.; Gohain, A.; Hussain, I.; Haider, B.; Davidson, E.; MacMillan, B. Carefully Designed Water-Based Drill-In Fluid and Filter Cake Removal System Improve Reservoir Producibility and Reduce Well Completion Costs. In Proceedings of the SPE Formation Damage Conference, Scheveningen, The Netherlands, 27-29 May 2009.

18. Leschi, P.; Demarthon, G.; Davidson, E.; Clinch, D. Delayed Release Acid System for Cleanup of Al Khalij Horizontal Open Hole Drains. In Proceedings of the SPE International Symposium and Exhibition on Formation Damage Control, Lafayette, LA, USA, 15-17 February 2006.

19. Zubail, M.A.; Al-Kuait, A.M.S.; Al-Yateem, K.S.; El Bialy, M.; Maghrabi, S.; Olivares, T.; Ezell, R.G. Improved Producibility after Delayed Filter Cake Breaker Treatment in the Safaniya Offshore Field in Saudi Arabia. In Proceedings of the SPE Kuwait International Petroleum Conference and Exhibition, Kuwait City, Kuwait, 10-12 December 2012.

20. Quintero, L.; Jones, T.; Clark, D.E. One-Step Acid Removal of an Invert Emulsion. In Proceedings of the European Formation Damage Conference, Scheveningen, The Netherlands, 25-27 May 2005.

21. Quintero, L.; Jones, T.; Pietrangeli, G. Phase Boundaries of Microemulsion Systems Help to Increase Productivity. In Proceedings of the SPE European Formation Damage Conference, Noordwijk, The Netherlands, 7-10 June 2011.

22. Ezrahi, S.; Aserin, A.; Garti, N. Aggregation Behaviour in One-Phase (Winsor IV) Microemulsion systems. In Handbook of Microemsulion Science and Technology; Kumar, P., Mittal, K.L., Eds.; Marcel Dekker, Inc.: New York, NY, USA, 1999; p. 185.

23. Salager, J.L.; Anton, R. Ionic Microemulsions, in Handbook of Microemulsion Science and Technology; Kumar, P., Mittal, K.L., Eds.; Marcel Dekker, Inc.: New York, NY, USA, 1999; p. 247.

24. Bohlen, D.S.; Vinson, P.K.; Davis, H.T.; Scriven, L.E.; Xie, M.; Zhu, X.; Miller, G.W. Generic Patterns in the Microstructure of Midrange Microemsulions, in Organized Solutions, Surfactant Science Series; Friberg, S.E., Lindman, B., Eds.; Marcel Dekker, Inc.: New York, NY, USA, 1992; p. 145.

25. Zana, R.; Lang, J. Dynamic of Microemulsions, in Micremulsion; Structure and Dynamics; Friderg, S.E., Bothorel, P., Eds.; CRC Press, Inc.: Boca Raton, FL, USA, 1987; p. 153.

26. Brege, J.; El Sherbeny, W.; Quintero, L.; Jones, T. Using Microemulsion Technology to Remove Oil-based Mud in Wellbore Displacement and Remediation Applications. In Proceedings of the North Africa Technology Conference and Exhibition, Cairo, Egypt, 20-22 February 2012.

27. Al-Otaibi, M.A.; BinMoqbil, K.H.; Al-Rabba, A.S.; Abitrabi, A.N. Single-Stage Chemical Treatment for Oil-Based Mudcake Cleanup: Field Case and Laboratory Studies. In Proceedings of the SPE International Symposium and Exhibition on Formation Damage Control, Lafayette, LA, USA, 10-12 February 2010. 
28. Kumar, V.A.; Balraj AAIshaq, G.K.; Prakash, B.L.; Imran, J.A.; Al Saqer, Q.R.; El Sherbeny, W.; Pino, A.R.; Gad-Alla, A.E.; Olivaresantunez, T. Overcoming OBM Filter Cake Damage Using Micro-Emulsion Remediation Technology across a High-Temperature Formation. In Proceedings of the SPE International Conference \& Exhibition on Formation Damage Control, Lafayette, LA, USA, 24-26 February 2016.

29. Bourrel, M.; Chambu, C.; Schechter, R.S. The Topology of Phase Boundaries for Oil/Brine/Surfactant Systems and Its Relationship to Oil Recovery. SPE J. 1982, 22, 28-36. [CrossRef]

30. Pietrangeli, G.; Quintero, L.; Jones, T.A.; Benaissa, S.; Menezes, C.A.; Aubry, E.; Poitrenaud, H.; Furgier, J.N. Overcoming Wellbore Cleanup Challenges in Deepwater Wells in West Africa. In Proceedings of the SPE International Symposium and Exhibition on Formation Damage Control, Lafayette, LA, USA, 26-28 February 2014.

31. Zhou, J.; Nasr-El-Din, H.A.; Socci, D.; Holcomb, J. A Cost-Effective Application of New Surfactant/Oxidant System to Enhance the Removal Efficiency of Oil-Based Mud Filter Cake. In Proceedings of the SPE Western Regional Meeting, Garden Grove, CA, USA, 22-27 April 2018.

(C) 2019 by the author. Licensee MDPI, Basel, Switzerland. This article is an open access article distributed under the terms and conditions of the Creative Commons Attribution (CC BY) license (http://creativecommons.org/licenses/by/4.0/). 